\title{
PENGARUH GAYA KEPEMIMPINAN TRANSAKSIONAL DAN TRANSFORMASIONAL TERHADAP KINERJA GURU DENGAN KEPUASAN KERJA SEBAGAI VARIABEL INTERVENING PADA SMK NEGERI DI ACEH UTARA
}

\author{
Mahdi $^{1}$, Aiyub $^{2 *}$, Darmawati $^{3}$ \\ Program Pasca Sarjana Ilmu Manajemen Universitas malikussaleh \\ Email : mahdist546@gmail.com, aiyub@unima.ac.id, darmawati@unimal.ac.id
}

\begin{abstract}
ABSTRAK
The teacher is one of the most important components in improving the intelligence of the nation's children. Teacher performance is an important factor in realizing these goals. Efforts to improve teacher performance are one of the priorities of the country. This study aims to determine the effect of transactional and transformational leadership styles on teacher performance through job satisfaction. The data used are primary data by distributing questionnaires to 144 teachers at the State Vocational High School (SMK) in North Aceh Regency. The method used to analyze data is the Structural Equation Modeling (SEM) Method with the Amos device. The results found that transactional leadership and transformational leadership have a significant effect on job satisfaction and teacher performance and job satisfaction has a direct effect on teacher performance. Furthermore, it was found that job satisfaction mediated the effect of transactional leadership and transformational leadership on the performance of North Aceh District Vocational School teachers. Based on the results of the study, it is expected that school leaders or principals, to improve teacher performance, need to maintain the application of transactional and transformational leadership styles and give priority to increasing job satisfaction.
\end{abstract}

Keywords : Transactional leadership, transformational leadership, job satisfaction and teacher performance

\section{Pendahuluan}

Guru yang memiliki kinerja yang tinggi adalah sangat penting dalam mencapai tujuan pendidikan yang berkualitas. Berhasil tidaknya suatu lembaga pendidikan dalam mencapai tujuannya sangat dipengaruhi oleh kinerja dari individu guru yang ada di lembaga tersebutdalam meningkatkan mutu pendidikan. Dengan kata lain tanpa kinerja yang baik maka tujuan yang telah ditetapkan sangat sulit untuk dicapai. Oleh karena itu kinerja individu guru sangat diperlukan dalam dunia pendidikan. Mengingat betapa pentingnya kinerja guru, maka lembaga pendidikan harus mengetahui faktor-faktor apa saja yang mempengaruhi kinerja. Pengetahuan ini sangat penting dan bermanfaat bagi pimpinan pada lembaga pendidikan untuk membuat program pengembangan Sumber Daya Manusia (SDM) khususnya untuk mencapai kinerja guru yang optimal. Pada akhirnya keberhasilan dalam peningkatan kinerja guru akan mencerminkan tingkat kompetisi lembaga pendidikan tersebut.

Berdasarkan pendapat dan kajian empirikal di atas dapat disimpulkan bahwa secara umum ditemukan kepuasan kerja, kepemimpinan transaksional dan 
kepemimpinan transformasional berpengaruh positif dan signifikan terhadap kinerja pegawai, namun demikian kesimpulan ini belumlah konsisten karena masih terdapat beberapa penelitian yang menemukan bahwa kepuasan kerja, kepemimpinan transaksional tidak berpengaruhsignifikan terhadap kinerja pegawai. Oleh karena itu sangat perlu suatu kajian lanjutan untuk dilakukan bagi menemukan kesimpulan yang konsisten dan sejalan dalam mendukung penelitian sebelumnya.

Di samping itu kepala sekolah juga mendorong kemampuan intelejensi, rasionalitas, dan pemecahan masalah yang dihadapi oleh bawahannya dengan hati-hati, menganjurkan pengikutnya untuk mengkaji ulang masalah serta menciptakan kesiapan untuk berubah dalam pemikiran. Kepala sekolah juga secara umum memiliki kemampuan untuk memotivasi pengikutnya agar menhasilkan kinerja yang luar biasa serta mengkomunikasikan ekspektasi yang tinggi dan menjelaskan tujuan yang penting dengan cara yang sederhana, menghadirkan pandangan mengenai masa depan yang optimistik dan bisa dicapai serta menciptakan kebutuhan akan prioritas dan tujuan. Berdasarkan pengamatan ditemukan bahwa hanya terdapat sebagian kecil pimpinan atau kepala sekolah yang memiliki kharisma yang dapat memberi pengaruh yang ideal. Terdapat pemimpin yang belum sepenuhnya menjadi contoh teladan dan acuan untuk orang-orang di sekitarnya. Namun demikian terdapat juga pimpinan yang memiliki kompetensi yang luar biasa dan menggunakan kekuasaannya untuk mendapatkan hasil yang positif.

Berdasarkan uraian di atas dapat diketahui bahwa secara teoritis masih terdapat perbedaan pandangan berhubungan dengan faktor-faktor yang mempengaruhi kinerja. Secara empirikal juga ditemukan terdapat hasil penelitian yang belum konsisten diantara para peneliti sebelumnya. Secara fenomena juga diketahui adanya persoalan kinerja yang belum optimal dan juga kepuasan kerja yang belum sepenuhnya dirasakan oleh kebanyakan guru.

\section{Kajian Pustaka}

\section{Pengertian Kepemimpinan}

Kepemimpinan merupakan salah satu unsur penting dalam sebuah organisasi. Keberhasilan organisasi dalam mencapai tujuan yang telah ditetapkan sangat tergantung kepada pola kepemimpinan dalam organisasi. Kepemimpinan menjadi unsur penting karena kepemimpinanlah yang bertanggung jawab dalam menentukan kebijakan dan arah dari suatu organisasi. Maju mundurnya organisasi sangat tergantung pada kepemimpinan dalam mengarahkan dan menangani organisasi. Banyak pimpinan yang sukses membawa organisasinya ke arah kemajuan, namun tidak sedikit pimpinan yang gagal membawa organisasi ke arah kemajuan. Keberhasilan dalam mengarahkan organisasinya dalam mencapai kemajuan sangat tergantung pada pola atau gaya kepemimpinan yang dianut oleh seorang pemimpin. Gaya kepemimpinan akan menentukan orientasi dari seorang pemimpin dalam mengelola sumber daya yang ada dalam organisasi. Ada pimpinan yang cenderung beorientasi kepada tugas atau produksi dan mengabaikan pada orientasi kepada pegawai ataupun sebaliknya atau keduaduanya. Perbedaan orientasi kepemimpinan akan memberi pengaruh yang berbeda terhadap organisasinya. 


\section{Gaya Kepemimpinan}

Pada dasarnya setiap pemimpin memiliki cara, gaya dan perilaku yang berbeda dalam memimpin dan mempengaruhi pengikutnya. Perbedaan perilaku, cara dan gaya dalam memimpin atau mempengaruhi orang lain sering disebut dengan gaya kepemimpinan. Gaya kepemimpinan pada dasarnya mengandung pengertian sebagai suatu perwujudan tingkah laku dari seorang pemimpin, yang menyangkut kemampuannya dalam memimpin.Perwujudan tersebut biasanya membentuk suatu pola atau bentuk tindakan tertentu.Bawahan yang puas akan gaya kepemimpinan yang diterapkan oleh atasannya tidak hanya patuh terhadap perintah yang diberikan, namun juga memiliki keterlibatan lebih dalam organisasinya (Wu et al., 2007). Hal ini tercermin dalam kesetiaan atau loyalitas bawahan terhadap atasan.

\section{Kempimpinan Transaksional}

Salah satu gaya kepemimpinan adalah kepemimpinan transaksional. Kepemimpinan traksaksional adalah salah satu gaya kepemimpinan yang terdapat dalam sebuah organisasi. Terdapat banyakpendapat ahli mengenai gaya kepemimpinan traksaksional. Misalnya menurut Howell dan Avolio (1993), mendefinisikan bahwa kepemimpinan transaksional adalah suatu gaya kepemimpinan yang menekankan pada hubungan pemimpin dan pengikut berdasarkan pada suatu rangkaian pertukaran atau persetujuan antara pemimpin dan pengikut. Sedangkan menurut Bass (1990) mendefinisikan kepemimpinan transaksional sebagai model kepemimpinan yang melibatkan suatu proses pertukaran (exchange process) di mana para pengikut mendapat reward yang segera dan nyata setelah melakukan perintah-perintah pemimpin. Selanjutnya menurut Shane dan Glinow (2003) mendefinisikan kepemimpinan transaksional sebagai kepemimpinan yang membantu orang mencapai tujuan mereka sekarang secara lebih efisien seperti menghubungkan kinerja pekerjaan dengan penghargaan yang dinilai dan menjamin bahwa karyawan mempunyai sumber daya yang diperlukan untuk menyelesaikan pekerjaan.

\section{Kepemimpinan Transformasional}

Terdapat beberapa pandangan para ahli tentang definisi dari kepemimpinan transformasional. Dalam kaitannya dengan kepemimpinan transformasional, Bass (Stone et al, 2004) mengatakan sebagai berikut: "Transformational leaders transform the personal values of followers to support the vision and goals of the organization by fostering an environment where relationships can be formed and by establishing a climate of trust in which visions can be shared". Selanjutnya, secara operasional Bass (Gill et al, 2010) memaknai kepemimpinan transformasional sebagai berikut: "Leadership and performance beyond expectations". Sedangkan Tracy and Hinkin (Gill et al, 2010) memaknai kepemimpinan transformasional sebagai berikut: "The process of influencing major changes in the attitudes and assumptions of organization members and building commitment for the organization's mission or objectives".

\section{Kepuasan Kerja}

Banyak pendapat dan pandangan para ahli tentang definisi dari kepuasan kerja, misalnya yang dikemukakan oleh Robins (2009), mengemukakan bahwa kepuasan kerja adalah sebagai suatu sikap umum seorang individu terhadap pekerjaannya. Pekerjaan menurut interaksi dengan rekan sekerja dan atasan, 
mengikuti aturan dan kebijakan organisasi, memenuhi standar kinerja, hidup pada kondisi kerja yang sering kurang dari ideal, dan hal serupa lainnya.

Berikutnya adalah menurut Kreitner (2005), menyebutkan bahwa kepuasan kerja adalah respons emosional terhadap pekerjaan seseorang.Gibson, Ivanevich dan Donnelly (2002) mengatakan bahwa kepuasan kerja adalah ungkapan perasaan seseorang tentang kesejahteraan untuk melakukan pekerjaan bahwa kepuasan kerja adalah sikap seseorang terhadap pekerjaan. Bahwa sikap itu berasal dari persepsi mereka tentang pekerjaan, persepsi itu adalah proses kognitif (pemberian arti) yang digunakan oleh seseorang untuk menafsirkan dan memahami cara pandang individu dalam melihat hal yang sama dengan cara yang berbeda. Kepuasan kerja juga adalah sebagai hasil dari persepsi karyawan mengenai seberapa baik pekerjaan mereka dan memberikan hal yang dinilai penting.

\section{Kinerja Guru}

Kinerja pegawai yang baik akan muncul secara intern dalam pribadi pegawai sebagai individu dan secara ekstern dapat dimunculkan melalui stimulus kepada aspek-aspek yang menyebabkan seorang individu tidak mampu atau produktifitasnya rendah. Kinerja pegawai akan muncul apabila pegawai merasakan kenyamanan dan kepuasan dalam bekerja.

Menurut Torang (2012) "Kinerja adalah kuantitas atau kualitas hasil kerja individu atau sekelompok di dalam organisasi dalam melaksanakan tugas pokok dan fungsi yang berpedoman pada norma, standar operasional prosedur kriteria dan ukuran yang telah ditetapkan atau yang berlaku dalam organisasi”. Selain itu Colquitt, Lepine, dan Wesson (2009:37) mendefinisikan "Kinerja (job performance) sebagai nilai satu kesatuan dari perilaku karyawan sebagai kontribusi dan lainnya secara positif untuk pemenuhan tujuan organisasi”.

\section{Kerangka Konseptual}

Menurut Haryoko dalam Iskandar (2010) bahwa kerangka konsep adalah penjelasan secara teoritis model konseptual variabel-variabel penelitian, tentang bagaimana hubungan teori-teori yang berhubungan dengan variabel-variabel penelitian yang ingin diteliti, yaitu variabel bebas dengan variabel terikat. Kerangka konseptual penelitian perlu dijelaskan apabila penelitian tersebut terdiri dari dua variabel atau lebih secara mandiri, maka perlu dilakukan deskripsi teoritis masing-masing variabel dengan argumentasi terhadap variasi besarnya variabel yang diteliti. Sedangkan menurut Sugiyono (2013), mengatakan bahwa kerangka konseptual adalah sintesa tentang hubungan antara variabel yang disusun dari berbagai teori yang telah dideskripsikan.

Kerangka konseptual dalam penelitian dibangun melalui hubungan variabel dependen, variabel independen dan variabel intervening.Variabel independen terdiri dariKepemimpinan Transaksional (KTS) dan Kepemimpinan Transformasional (KTF).Variabel dependen terdiri dariKepuasan Kerja (KKG)dan Kinerja Guru (KGR)

Berdasarkan uraian di atas, dapat digambarkan hubungan variabel, kepemimpinan transaksional, kepemimpinan transformasional dan kepuasan kerja terhadap kinerja guru dalam bentuk kerangka konsep penelitian seperti pada gambar berikut: 


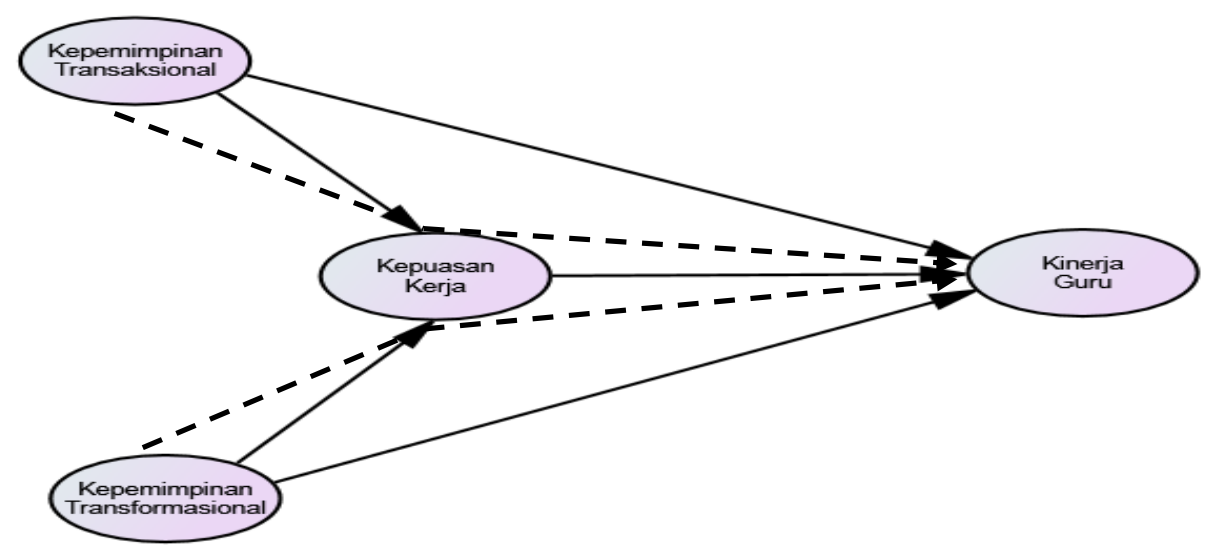

Gambar Kerangka Konseptual

Dari kerangka konseptual penelitian, dirumuskan hipotesis penelitian sebagai berikut :

Hipotesis 1: Gaya Kepemimpinan Transaksional berpengaruh signifikan terhadap kepuasan kerja guru pada SMK Negeri di Kabupaten Aceh Utara.

Hipotesis 2: Gaya Kepemimpinan Transformasional berpengaruh signifikan terhadap kepuasan kerja guru pada SMK Negeri di Kabupaten Aceh Utara.

Hipotesis 3 : Gaya Kepemimpinan transaksional berpengaruh signifikan terhadap kinerja guru pada SMK Negeri di Kabupaten Aceh Utara.

Hipotesis 4 : Gaya Kepemimpinan transformasional berpengaruh signifikan terhadap kinerja guru pada SMK Negeri di Kabupaten Aceh Utara.

Hipotesis 5 : Kepuasan kerja berpengaruh signifikan terhadap kinerja guru pada SMK Negeri di Kabupaten Aceh Utara.

Hipotesis 6 : Kepuasan Kerja memediasi pengaruh gaya kepemimpinan transaksional terhadap kinerja guru pada SMK Negeri di Kabupaten Aceh Utara.

Hipotesis 7 : Kepuasan Kerja memediasi pengaruh gaya kepemimpinan transformasional terhadap kinerja guru pada SMK Negeri di Kabupaten Aceh Utara.

\section{Metode Penilitian}

\section{Lokasi dan Objek Penelitian}

Lokasi penelitian ini dilakukan pada SMK di Kabupaten Aceh Utara. Sedangkan yang menjadi objek penelitian adalah guru yang mengajar pada SMK di Kabupaten Aceh Utara.

\section{Populasi dan Sampel \\ Populasi}

Populasi merupakan gabungan seluruh elemen berupa peristiwa, hal atau orang yang memiliki ciri-ciri sama yang menjadi pusat perhatian peneliti karena itu populasi dianggap sebagai sebuah area penelitian yang luas (Ferdinand, 2006). Populasi penelitian ini adalah seluruh guru SMK Negeri di Kabupaten Aceh Utara yang berjumlah 144 orang dari 7 sekolah. 


\section{Sampel}

Model penelitian yang digunakan dalam penelitian ini adalah model Structural Equation Modelling (SEM), dimana jumlah sampel yang ideal antara 100-200 (Hair et al., 2009) dan juga mempertimbangkan jumlah indikator yang ada dalam model.Hair et al. (2009) mengatakan bahwa untuk menentukan jumlah sampel dapat berjumlah 5-10 dari jumlah indikator. Dalam penelitian ini terdapat 21 indikator sehingga jumlah sampel bisa berkisar antara 105-210 responden.

Jumlah sampel dalam penelitian ini adalah keseluruhan populasi yaitu sebanyak 144 (sampel jenuh). Jumlah sampel ini juga masih memenuhi kriteria yang disyaratkan oleh Hair at al. (2009), yaitu sampel ideal berkisar antara 100200.

Teknik pengambilan sampel dilakukan dengan menggunakan teknik probability sampling (random sampling), dengan pendekatan simple random sampling (sampel acak sederhana), di mana setiap anggota populasi memiliki kesempatan yang sama untuk dipilih menjadi sampel. Pemilihan sampel dengan pendekatan accidental dimana populasi yang berasal cluster atau kelompok sampel adalah mereka yang mudah pertama ditemui dalam waktu pada saat proses penyebaran kuesioner dilakukan.

\section{Metode Analisis Data}

Teknik analisis data yang digunakan dalam penelitian ini adalah SEM (Structural Equation Modeling) dengan alat analisis yang digunakan adalah program AMOS (Analysis of Moment Structure). SEM adalah sekumpulan teknikteknik statistikal yang memungkinkan pengujian sebuah rangkaian hubungan relatif murni "rumit" secara simultan (Ferdinand, 2006). SEM merupakan penggabungan antara dua konsep statistika, yaitu konsep analisis faktor yang masuk pada model pengukuran (measurement model) dan konsep regresi melalui model struktural (structural model).

\section{Hasil Analisis Full Model Sebelum Modifikasi}

Untuk mengetahui apakah model persamaan struktural yang dibentuk dalam penelitian ini telah memenuhi kriteria Goodness of Fit (GOF), maka dilakukan pengujian kesesuaian model terhadap full model's yang meliputi semua variabel. Hasil pengujian full model sebelum modifikasi ditampilkan dalam Gambar di bawah ini : 


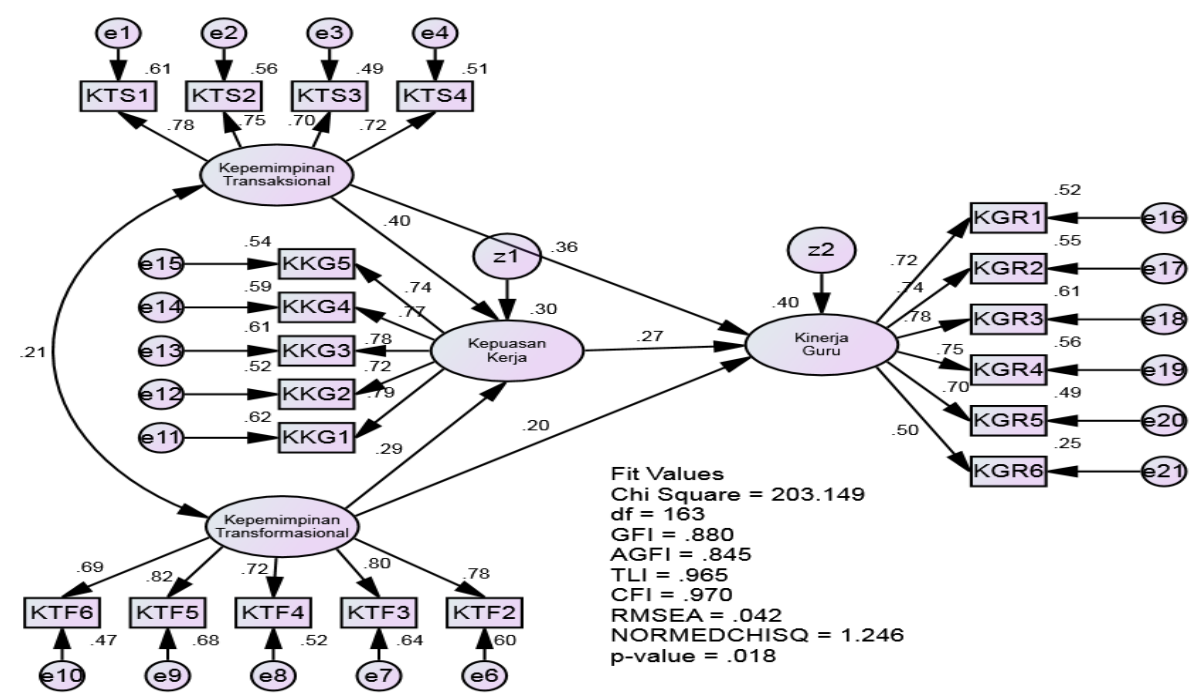

\section{Gambar Full Model Penelitian Sebelum Modifikasi}

Berdasarkan angka-angka yang ditunjukkan dalam Gambar di atas, dapat diterangkan bahwa model penelitian belum sepenuhnya memenuhi kriteria goodness of fit indeks $(G O F)$, karena terdapat tiga kriteria yang belum memenuhi nilai yang disyaratkat, yaitu GFI dan AGFI dan p-value, ketiganya memiliki nilai yang marginal. Oleh karena itu model penelitian ini harus dimodifikasi seperlunya sesuai dengan kriteria modifikacation indise. Nilai GOF secara lengkap ditampilkan dalam Tabel di bawah ini :

Tabel Goodness of Fit Full Model Sebelum Modifikasi

\begin{tabular}{|c|c|c|c|c|}
\hline No & Kriteria & Nilai Diharapkan & Nilai Hasil & Kesimpulan \\
\hline 1 & Chi Square & Diharapkan Kecil & 203,149 & Baik \\
\hline 2 & Goodness Of Fit Indeks (GFI) & $>0,90$ & 0,880 & Marginal \\
\hline 3 & $\begin{array}{l}\text { Adjusted Goodness Fit Of Index } \\
(A G F I) \text {. }\end{array}$ & $>0,90$ & 0,845 & Marginal \\
\hline 4 & Tucker Lewis Index (TLI) & $>0,90$ & 0,965 & Baik \\
\hline 5 & Comparative Fit Index (CFI) & $>0,90$ & 0,970 & Baik \\
\hline 6 & $\begin{array}{l}\text { Root Mean Square Error of } \\
\text { Approximation (RMSEA) }\end{array}$ & $<0,05-0,08$ & 0,042 & Baik \\
\hline 7 & $C M I N / D F$ & $<2,00$ & 1,246 & Baik \\
\hline 8 & $P$-Value & $>0,05$ & 0,018 & Marginal \\
\hline
\end{tabular}

\section{Hasil Analisis Full Model Setelah Modifikasi}

Setelah dilakukan modifikasi model dengan cara melakukan kovarian antar error seperti yang direkomendasikan oleh sistem pada bagian modification Indies, maka model telah fit seperti ditunjukkan dalam Gambardi bawah ini : 


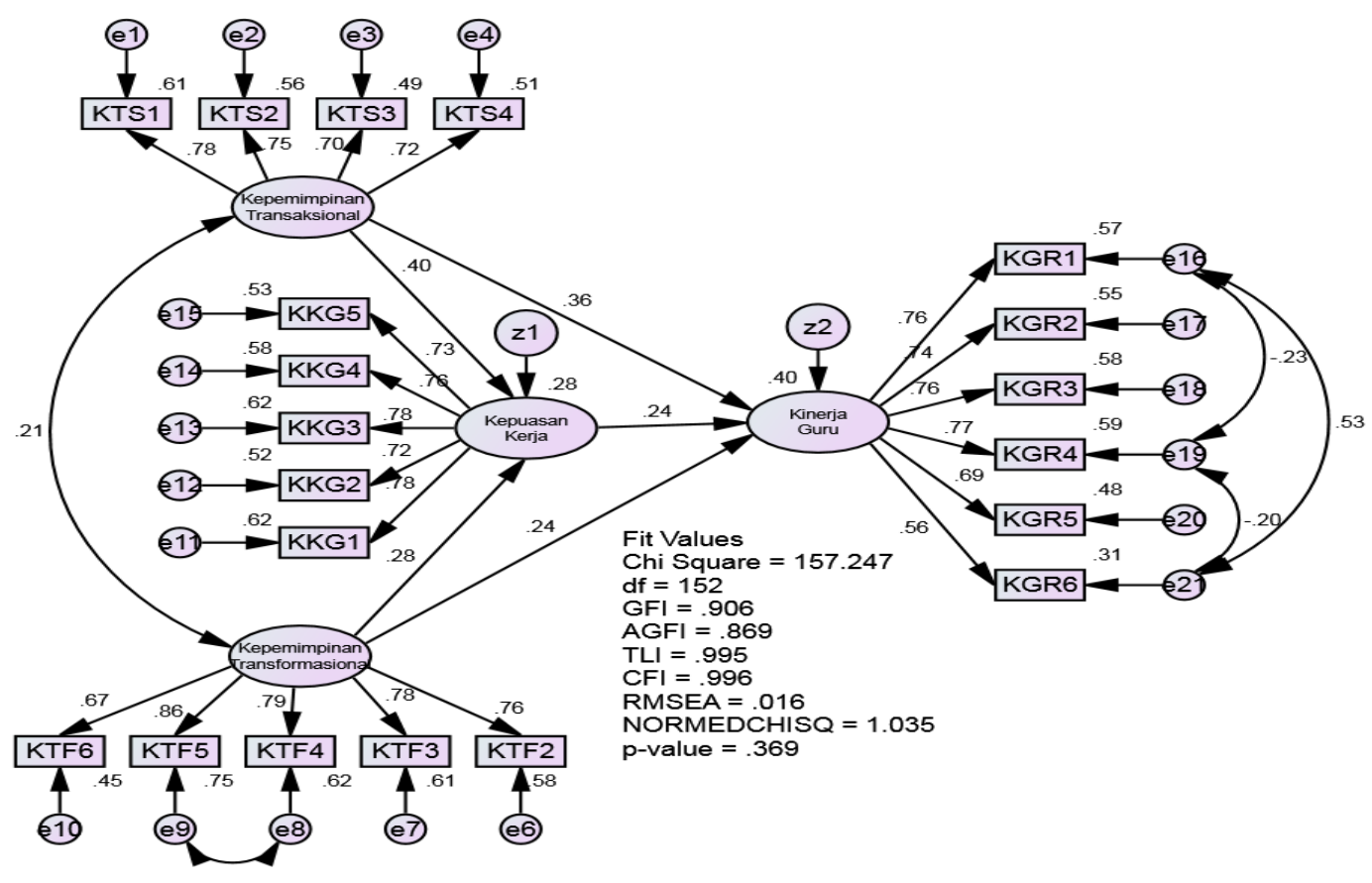

Gambar Full Model Penelitian Setelah Modifikasi

Berdasarkan Gambar di atas dapat dijelaskan bahwa modifikasi yang dilakukan yaitu sebanyak 4 buah korelasi yaitu e8-e9, e18-e21, e18-e19, dan e19e21. Setelah dilakukan modifikasi, model penelitian telah fit dengan data. Nilai dari Goodness of Fit setelah model dimodifikasi dapat ditampilkan dalam Tabel di bawah.

Tabel Kriteria Goodness of Fit Full Model Setelah Modifikasi

\begin{tabular}{|c|c|c|c|c|c|}
\hline No & Kriteria & $\begin{array}{c}\text { Nilai } \\
\text { Diharapkan }\end{array}$ & $\begin{array}{c}\text { Nilai } \\
\text { Sebelum } \\
\text { Modifikasi }\end{array}$ & $\begin{array}{c}\text { Nilai } \\
\text { Setelah } \\
\text { Modifikasi }\end{array}$ & Kesimpulan \\
\hline 1 & Chi Square & $\begin{array}{l}\text { Diharapkan } \\
\text { Kecil }\end{array}$ & 203,149 & 157,247 & Baik \\
\hline 2 & $\begin{array}{l}\text { Goodness of Fit Indeks } \\
(G F I)\end{array}$ & $>0,90$ & 0,880 & 0,906 & Baik \\
\hline 3 & $\begin{array}{l}\text { Adjusted Goodness Fit of } \\
\text { Index (AGFI). }\end{array}$ & $>0,90$ & 0,845 & 0,869 & Marginal \\
\hline 4 & Tucker Lewis Index (TLI) & $>0,90$ & 0,965 & 0,995 & Baik \\
\hline 5 & $\begin{array}{l}\text { Comparative Fit Index } \\
(C F I)\end{array}$ & $>0,90$ & 0,970 & 0,996 & Baik \\
\hline 6 & $\begin{array}{l}\text { Root Mean Square Error of } \\
\text { Approximation (RMSEA) }\end{array}$ & $<0,05-0,08$ & 0,042 & 0,016 & Baik \\
\hline 7 & $C M I N / D F$ & $<2,00$ & 1,246 & 1,035 & Baik \\
\hline 8 & $P$-Value & $>0,05$ & 0,018 & 0,369 & Baik \\
\hline
\end{tabular}




\section{Hasil Estimasi Nilai Parameter}

Untuk mengetahui pengaruh, arah pengaruh dan signifikansi pengaruh variabel eksogen terhadap variabel endogen maka dilakukan analisis estimasi nilai parameter. Nilai koefisien yang digunakan adalah nilai estimate standardized regression weights seperti yang diperlihatkan dalam Tabel di bawah ini :

Tabel Estimate Standardized Regression Weights

\begin{tabular}{|c|c|c|c|c|c|c|}
\hline & Hubungan Variabel & $\begin{array}{l}\text { Unstd. } \\
\text { Estimate }\end{array}$ & $\begin{array}{l}\text { Stand. } \\
\text { Estimate }\end{array}$ & S.E. & C.R. & $\mathrm{P}$ \\
\hline Kepuasan_Kerja & $<---$ Kepem._Transaksional & 0.367 & 0.400 & 0.089 & 4.106 & $* * *$ \\
\hline Kepuasan_Kerja & <--- Kepem._Transformasional & 0.286 & 0.278 & 0.092 & 3.115 & 0.002 \\
\hline Kinerja_Guru & <--- Kepem._Transaksional & 0.336 & 0.359 & 0.095 & 3.537 & $* * *$ \\
\hline Kinerja_Guru & <--- Kepemim._Transformasional & 0.251 & 0.239 & 0.090 & 2.777 & 0.005 \\
\hline Kinerja_Guru & $<---$ Kepuasan_Kerja & 0.249 & 0.244 & 0.102 & 2.435 & 0.015 \\
\hline
\end{tabular}

\section{Hasil Perhitungan Pengaruh Total, Langsung dan Tidak Langsung}

Hasil perhitungan pengaruh langsung, tidak langsung dan pengaruh total dapat dilihat dalam Tabel di bawah ini :

Tabel Pengaruh Langsung, Tidak Langsung dan Total

\begin{tabular}{lccc}
\hline \multicolumn{1}{c}{ Variabel } & $\begin{array}{c}\text { Gaya } \\
\text { Kepemimpinan } \\
\text { Transaksional }\end{array}$ & $\begin{array}{c}\text { Gaya } \\
\text { Kepemimpinan } \\
\text { Transformasional }\end{array}$ & Kepuasan Kerja \\
\hline Kepuasan_Kerja & Pengaruh Total & & \\
Kinerja_Guru & 0.400 & 0.278 & - \\
\hline & 0.456 & 0.307 & - \\
\hline Kepuasan_Kerja & Pengaruh Langsung & & 0.244 \\
Kinerja_Guru & 0.400 & 0.278 & - \\
\hline & 0.359 & 0.239 & - \\
\hline Kepuasan_Kerja & Pengaruh Tidak Langsung & - & - \\
Kinerja_Guru & - & 0.068 & \\
\hline
\end{tabular}

Sumber: Data diolah 2020

Berdasarkan nilai-nilai yang ditunjukkan dalam Tabel di atas dapat dijelaskan tentang pengaruh langsung, pengaruh tidak langsung dan pengaruh total dari masing-masing variabel sebagai berikut:

a. Pengaruh Langsung:

a. Pengaruh langsung kepemimpinan transaksional terhadap kepuasan kerja adalah sebesar 0,400 .

b. Pengaruh langsung kepemimpinan transformasional terhadap kepuasan kerja adalah sebesar 0,278.

c. Pengaruh langsung kepemimpinan transaksional terhadap kinerja guru adalah sebesar 0,359 . 
d. Pengaruh langsung kepemimpinan transformasional terhadap kepuasan kerja adalah sebesar 0,239 .

e. Pengaruh langsung kepuasan terhadap kinerja guru adalah sebesar 0,244.

b. Pengaruh tidak langsung:

a. Pengaruh tidak langsung variabel kepemimpinan transaksional terhadap kinerja guru melalui kepuasan kerja adalah sebesar 0,098.

b. Pengaruh tidak langsung variabel kepemimpinan transformasional terhadap kinerja guru melalui kepuasan kerja adalah sebesar 0,068.

c. Pengaruh total:

a. Pengaruh total kepemimpinan transaksional terhadap kepuasan kerja adalah sebesar 0,400 .

b. Pengaruh total kepemimpinan transformasional terhadap kepuasan kerja adalah sebesar 0,278.

c. Pengaruh total kepemimpinan transaksional terhadap kinerja guru adalah sebesar 0,456.

d. Pengaruh total kepemimpinan transformasional terhadap kepuasan kerja adalah sebesar 0,307 .

e. Pengaruh total kepuasan terhadap kinerja guru adalah sebesar 0,244.

\section{Hasil Perhitungan Efek Mediasi}

Untuk memastikan apakah kepuasan kerja mediasi pengaruh antara kepemimpinan transaksional, kepemimpinan transformasional terhadap kinerja guru dilakukan uji efek mediasi dengan menggunakan kriteria atau tahapan yang dikembangkan oleh Baron dan Kenny (1986).

\section{Pengaruh Gaya Kepemimpinan Transaksional terhadap Kinerja Guru melalui Kepuasan Kerja}

Untuk mengetahui apakah kepuasan kerja memediasi hubungan antara kepemimpinan transaksional dengan kinerja guru ditampilkan dalam Gambar di bawah ini :

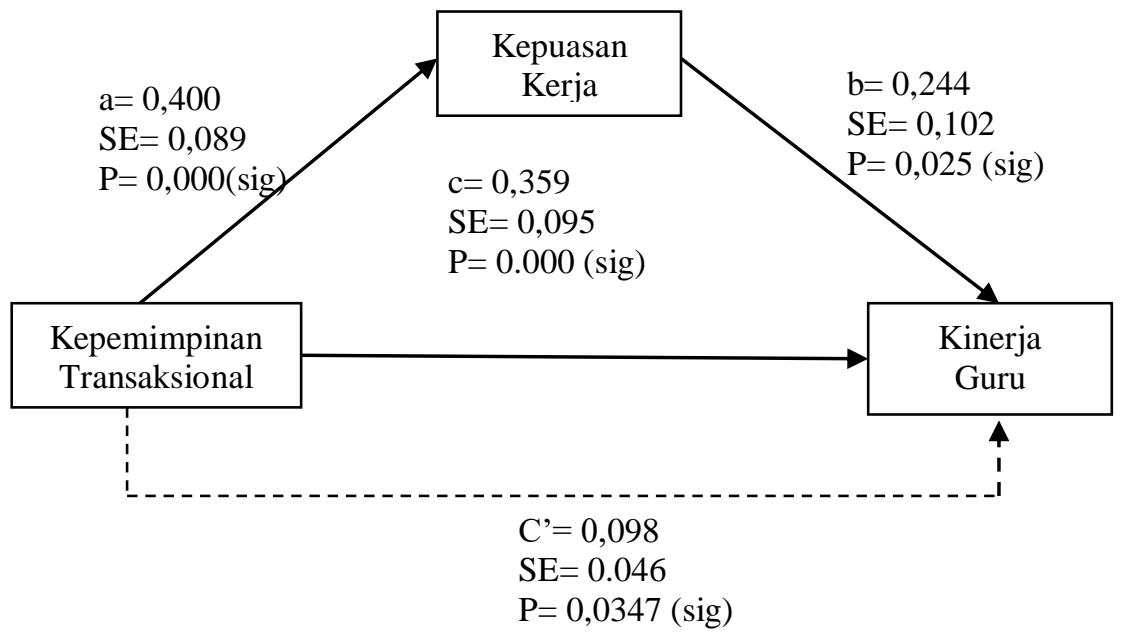

Gambar Pengujian Efek Mediasi KTS-KKG-KGR

Berdasarkan hasil perhitungan efek mediasi seperti yang ditampilkan dalam Gambar di atas dapat dijelaskan bahwa koefisien jalur a, jalur b dan jalur c adalah signifikan, dan jalur c' juga signifikan, maka dapat disimpulkan bahwa 
kepuasan kerja memediasi secara sebagian (partial mediation) pengaruh kepemimpinan transaksional terhadap kinerja guru SMK Negeri di Kabupaten Aceh Utara.

\section{Pengaruh Gaya Kepemimpinan Transformasional terhadap Kinerja Guru melalui Kepuasan Kerja}

Untuk mengetahui apakah kepuasan kerja mediasi pengaruh kepemimpinan transformasional terhadap kinerja guru ditampilkan dalam Gambar di bawah ini :

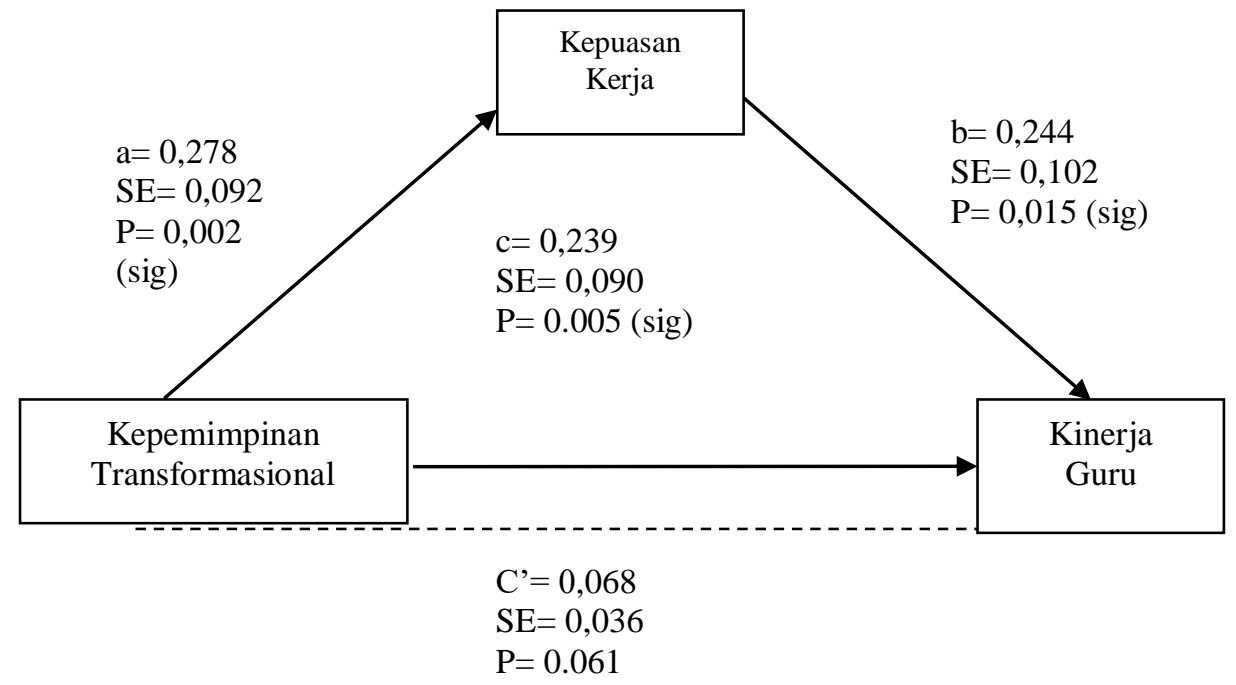

\section{Gambar Pengujian Efek Mediasi KTF-KKG-KGR}

Berdasarkan hasil perhitungan efek mediasi seperti yang ditampilkan dalam Gambar 5.14 dapat dijelaskan bahwa koefisien jalur a, jalur b dan jalur c adalah signifikan, dan jalur c' tidak signifikan, maka dapat disimpulkan bahwa kepuasan kerja memediasi secara penuh (full mediation) pengaruh kepemimpinan transformasional terhadap kinerja guru pada SMK Negeri Kabupaten Aceh Utara.

\section{Kesimpulan Pengujian Hipotesis}

Berdasarkan pembahasan seperti yang telah disampaikan di atas, maka dapat disimpulkan hasil pengujian hipotesis seperti dalam Tabel sebagai berikut:

Kesimpulan Pengujian Hipotesis

\begin{tabular}{|c|c|c|}
\hline Hipotesis & Pernyataan & Kesimpulan \\
\hline 1 & $\begin{array}{l}\text { Gaya Kepemimpinan Transaksional berpengaruh signifikan } \\
\text { terhadap kepuasan kerja guru pada SMK Negeri di } \\
\text { Kabupaten Aceh Utara. }\end{array}$ & Diterima \\
\hline
\end{tabular}

2 Gaya Kepemimpinan Transformasional berpengaruh

Diterima signifikan terhadap kepuasan kerja guru pada SMK Negeri di Kabupaten Aceh Utara

3 Gaya Kepemimpinan transaksional berpengaruh signifikan terhadap kinerja guru pada SMK Negeri di Kabupaten Aceh

Diterima Utara.

4 Gaya Kepemimpinan transformasional berpengaruh signifikan terhadap kinerja guru pada SMK Negeri di

Diterima 


\begin{tabular}{clc}
\hline Hipotesis & \multicolumn{1}{c}{ Pernyataan } & Kesimpulan \\
\hline \multirow{4}{*}{5} & Kabupaten Aceh Utara & \\
& $\begin{array}{l}\text { Kepuasan kerja berpengaruh signifikan terhadap kinerja } \\
\text { guru pada SMK Negeri di Kabupaten Aceh Utara. }\end{array}$ & Diterima \\
6 & $\begin{array}{l}\text { Kepuasan Kerja memediasi pengaruh gaya kepemimpinan } \\
\text { transaksional terhadap kinerja guru pada SMK Negeri di }\end{array}$ & Diterima \\
& Kabupaten Aceh Utara & Mediation) \\
& $\begin{array}{l}\text { Kepuasan Kerja memediasi pengaruh gaya kepemimpinan } \\
\text { transformasional terhadap kinerja guru pada SMK Negeri di }\end{array}$ & Diterima \\
& Kabupaten Aceh Utara & \\
\hline
\end{tabular}

\section{Implikasi Penelitian}

Penelitian ini mampu memberikan kontribusi yang bermanfaat bagi kemajuan dan pengembangan ilmu pengetahuan baik secara teoritis maupun secara praktis, khususnya dalam rangka penyusunan kebijakan dan pengambilan keputusan bagi managerial dalam sebuah organisasi.

\section{Kesimpulan}

Berdasarkan hasil penelitian seperti yang telah dijelaskan pada bagian pembahasan, maka dapat dirumuskan beberapa kesimpulan sebagai berikut:

1. Kepemimpinan transaksionalberpengaruh positif dan signifikan terhadap kepuasan kerja gurupada SMK Negeri di Kabupaten Aceh Utara, artinya apabila kepala sekolah meningkatkan intensitas penerapan gaya kepemimpinan transaksional maka akan meningkatkan kepuasan kerja guru pada SMK Negeri di Kabupaten Aceh Utara.

2. Kepemimpinan transformasionalberpengaruh positif dan signifikan terhadap kepuasan kerja gurupada SMK Negeri di Kabupaten Aceh Utara, artinya apabila kepala sekolah meningkatkan intensitas penerapan gaya kepemimpinan transformasional maka akan meningkatkan kepuasan kerja guru pada SMK Negeri di Kabupaten Aceh Utara.

3. Kepemimpinan transaksionalberpengaruh positif dan signifikan terhadap kinerja gurupada SMK Negeri di Kabupaten Aceh Utara, artinya apabila kepala sekolah meningkatkan intensitas penerapan gaya kepemimpinan transaksional maka akan meningkatkan kinerja guru pada SMK Negeri di Kabupaten Aceh Utara.

4. Kepemimpinan transformasionalberpengaruh positif dan signifikan terhadap kinerja gurupada SMK Negeri di Kabupaten Aceh Utara, artinya apabila kepala sekolah meningkatkan intensitas penerapan gaya kepemimpinan transformasional maka akan meningkatkan kinerja guru pada SMK Negeri di Kabupaten Aceh Utara.

5. Kepuasan kerjaberpengaruh positif dan signifikan terhadap kinerja gurupada SMK Negeri di Kabupaten Aceh Utara, artinya apabila tingkat kepuasan kerja guru meningkat maka akan meningkatkan kinerja guru pada SMK Negeri di Kabupaten Aceh Utara.

6. Kepuasan kerja memediasi secara sebagian (partial mediation) pengaruh kepemimpinan transaksional terhadap kinerja guru SMK Negeri di Kabupaten Aceh Utara, artinya kepemimpinan transaksional hanya 
sebagian saja mampu meningkatkan kinerja guru dan selebihnya dapat ditingkatkan melalui kepuasan kerja.

7. Kepuasan kerja memediasi secara penuh(full mediation) pengaruh kepemimpinan transformasional terhadap kinerja guru SMK Negeri di Kabupaten Aceh Utara, artinya kepemimpinan transformasional akan mampu meningkatkan kinerja guru hanya melalui kepuasan kerja.

\section{Saran}

Berdasarkan kesimpulan penelitian seperti yang telah diuraikan di atas, maka dapat diberikan beberapa saran sebagai berikut:

1. Dalam rangka meningkatkan kepuasan kerjaguru SMK Negeri di Kabupaten Aceh Utara, diharapkan kepada kepala sekolah untuk meningkatkan penerapan gaya kepemimpinan transaksional dan gaya kepemimpinan transformasional dalam memimpin atau mengelola sekolah dan para guru, karena kedua gaya kepemimpinan ini berpengaruh positif dan signifikan terhadap kepuasan kerja guru.

2. Untuk meningkatkan kinerja guru SMK Negeri di Kabupaten Aceh Utara, diharapkan kepada kepala sekolah untuk dapat mempertahankan penerapan gaya kepemimpinan transaksional dan gaya kepemimpinan transformasional dalam setiap arahan dan dalam menjalankan pengaruhnya sebagai pimpinan di sekolah, karena kedua gaya kepemimpinan ini berpengaruh positif dan signifikan terhadap kinerja guru.

3. Dalam rangka penerapan gaya kepemimpinan transaksional maka diharapkan kepada kepala sekolah dalam memberikan koreksi, sanksi atau hukuman hendaknya dapat dilakukan pendekatan persuasif terlebih dahulu dan melakukan dengan penuh bijaksana serta perlu mempertimbangkan psikologi dari para guru.

4. Rata-rata terendah jawaban responden untuk variabel kepemimpinan transformasional adalah pertanyaan "Pimpinan secara pasif menggunakan upaya koreksi/hukuman sebagai respons terhadap kinerja buruk/penyimpangan terhadap standard (KTS3), oleh karena itu dalam rangka penerapan gaya kepemimpinan transaksional maka diharapkan kepada kepala sekolah dalam memberikan koreksi, sanksi atau hukuman hendaknya dapat dilakukan pendekatan persuasif terlebih dahulu dan melakukan dengan penuh bijaksana serta perlu mempertimbangkan psikologi dari para guru.

5. Rata-rata terendah jawaban responden untuk variabel kepemimpinan transformasional adalah pertanyaan "Pimpinan memberikan stimulasi intelektual dengan mendorong kemampuan intelejensi, rasionalitas, dan pemecahan masalah individu dengan hati-hati" (KTF2). Oleh karena itu diharapkan kepada pimpinan atau kepala sekolah masih perlu meningkatkan pemberian stimulasi intelektual agar semakin tumbuh kemampuan dalam pemecahan masalah.

6. Para guru merasa belum puas terhadap gaji/upah yang diterima saat ini.Oleh karena itu pimpinan atau kepala sekolah diharapkan ke depan harus mengupayakan pemberian gaji/upah atau insentif harus benar-benar adil sesuai dengan kinerja yang diberikan. 
7. Kepuasan kerja adalah salah satu faktor penting dalam memediasi atau menjadi perantara tercapainya peningkatan kinerja baik secara sebagian maupun secara penuh, oleh karena itu pimpinan atau kepala sekolah harus dapat memberikan perioritas terhadap upaya meningkatkan kepuasan kerja karena tanpa kepuasan kerja maka penerapan gaya kepemimpinan transformasional tidak dapat berfungsi dalam meningkatkan kinerja.

\section{Keterbatasan Penelitian}

Keterbatasan penelitian adalah sesuatu yang berada diluar kemampuan peneliti untuk mengatasi atau menghindarinya. Adapun keterbatasan penelitian diantaranya adalah:

1. Metode pengumpulan data yang dilakukan adalah dengan cara menyebarkan kuesioner, karena kesibukan tertentu dari responden sehinga responden tidak dapat mengisi langsung kuesioner tersebut di hadapan peneliti tetapi sebagian responden meminta untuk dapat mengisi pada waktu lain dan kebanyakan mereka mengisi di rumah masing-masing. Dalam hal ini peneliti tidak dapat mengawasi sepenuhnya proses pengisian kuesioner yang dilakukan oleh responden sehingga bias dalam pengisian kuesioner tidak dapat dihindari. Adanya kemungkinan jawaban responden dipengaruhi oleh pendapat anggota keluarganya dan ini akan berdampak pada kualitas dan objektivitas responden dalam pengisian kuesioner.

2. Banyak faktor lain yang mempengaruhi kinerja guru namun dalam penelitian ini peneliti hanya menggunakan tiga variabel saja yaitu kepemimpinan transaksional, kepemimpinan transformasional, dan kepuasan kerja sehingga hasil penelitian yang didapat tidak dapat sepenuhnya mencerminkan keadaan yang sebenarnya di lapangan.

3. Indikator yang digunakan dalam penelitian ini sebagiannya adalah indikator yang umum bukan indikator khusus yang digunakan dalam bidang pendidikan, sehingga adanya kemungkinan para guru dalam mengisi kuesioner merasa asing dengan beberapa pertanyaan dalam kuesioner.

Meskipun temuan utama dari penelitian ini konsisten dengan studi sebelumnya yang dilakukan di berbagai organisasi dan sektor lainnya sehubungan dengan pengaruh gaya kepemimpinan transaksional dan transformasional, namun ukuran sampel berbeda-beda untuk sebagian besar kajian. Karena itu, hasil penelitian ini mungkin tidakdapat digeneralisasi. Pemilihan Variabel untuk penelitian selanjutnya harus ditinjau lebih lanjut dengan ukuran sampel yang berbeda, posisi pimpinan dan jenis organisasi

\section{DAFTAR PUSTAKA}

Abidin, Z., \& Nurmayanti, S. (2017). Pengaruh kepemimpinan transformasional terhadap organizational citizenship behavior dengan iklim organisasi sebagai variabel intervening (Studi Pada Kantor Dukcapil Kota Mataram). Jmm Unram-Master of Management Journal, 6(4).

Arifiani, Ratya Shafira, Astuti, Endang Siti, \& Ruhana, Ika. (2016). Pengaruh kepemimpinan transformasional terhadap organizational citizenship behavior dan kepuasan kerja (Studi pada Tenaga Perawat RSUD. Dr. Saiful Anwar Malang). Jurnal Administrasi Bisnis, 33(1), 127-135. 
Bass BM (1990). Bass and Stogdill's handbook of leadership: theory research and managerial applications 3rd edition. New York: Free Press.

Bass, B.M. dan Avilio, B.J. (1994).Introducing, Improving Organizational Leadership.New Jersey: Lawrence Erlbaum Associates.

Bernadin, H. (2007). Human Resource Management: An exponential approach. (4), 253-277.

Burns JM (1978). Leadership. New York: Harper \& Row.

Carroll, S, Keflas, R. dan Watson, C. (1964). Job Satisfaction and Productivity, Irwin: Illinois.

Chasanah, Nur. (2008). Analisis pengaruh empowerment, self-efficacy, budaya organisasi terhadap kepuasan kerja dalam meningkatkan kinerja karyawan, studi empiris pada karyawan PT. Mayora, Tbk Regional Jateng dan DIY. Tesis. Universitas Diponegoro, Semarang.

Dewi, Kadek Sintha. (2013). Pengaruh gaya kepemimpinan transformasional terhadap kepuasan kerja karyawan dan komitmen organisasi pada PT. KPM. Matrik: Jurnal Manajemen, Strategi Bisnis dan Kewirausahaan.

Ferdinand, Augusty. (2006). Structural Equation Model dalam Penelitian Manajemen, Semarang: BP Undip.

Ghozali, Imam (2013). Model Persamaan Struktural Konsep \& Aplikasi Dengan Program AMOS 21.0. (Edisi V) Semarang: Badan Penerbit Universitas Diponogoro.

--------(2008). Model Persamaan Struktural Konsep dan Aplikasi Dengan Program AMOS Ver. 16.0. Semarang: Badan Penerbit Universitas Diponegoro.

Gibson, James L, Ivancevich, John M, \& Donelly Jr, JH. (1998). Organisasi: Perilaku, struktur, proses, Edisi ke 8, Jilid 1 (terjemahan). Jakarta: Erlangga.

Hair, Joseph E, Rolph E. Andersen, Ronald L Tatham dan William C. Black., (1998). Multivariate Data Analysis, Fifth Edition. USA: Prentice Hall

Howell, Jane M dan Avolio, Bruce J. (1993). Transformational leadership, transactional leadership, locus of control, and support for innovation: Key predictors of consolidated-business-unit performance. Journal of Applied psychology, 78(6), 891.

Kathrin Rothfelder, Michael C. Ottenbacher dan Robert J Harrington. (2013). The impact of transformational, transactional and non-leadership styles on employee job satisfaction in theGerman hospitality industry. Sage JournalJuly 30, 2013 Research Articlehttps://doi.org/10.1177/1467358413493636

Katzell, A., Barret, C., dan Porker (1952) Motivation and Labor Turnover, Irwin Inc. Illions.

Keller, R.T. (1992). Transformational leadership and the performance of research

Kristianto, Dian., Suharnomo \& Ratnawati, Intan., (2012). Pengaruh Kepuasan Kerja Terhadap Kinerja Karyawan Dengan Komitmen Organisasional Sebagai Variabel Intervening. Studi pada RSUD Tugurejo Semarang, Jurnal Universitas Diponegoro.

Notoatmodjo,Soekidjo. (2010). Metodologi penelitian kesehatan. In: Jakarta: Rineka cipta.

Novitasari, Dwi, \& Fidiastuti, Fidiastuti. (2018). Pengaruh kepemimpinan transformasional, komitmen organisasi dan kepuasan kerja terhadap kinerja karyawan (Studi pada Puskesmas Kalibawang, Kabupaten Kulon 
Progo). Jurnal Riset Manajemen Sekolah Tinggi Ilmu Ekonomi Widya Wiwaha Program Magister Manajemen, 5(1), 17-31.

Porter, L. W. dan Lawler, E. E. (1974) "The Effect of Performance on Job Satisfaction." In Edwin A. Fleishman (ed) Studies in Personal and Industrial Psychology. Third Edition, Illinois.

Ratzell, R. A. (1964) Personal Values, Job satisfaction dan Job Behavior, Houghton Miffin Co. Boston.

Riaz, Adnan dan Haider, Mubarak Hussain. (2010). Role of transformational and transactional leadership on job satisfaction and career satisfaction. Business and Economic horizons, 1(1), 29-38.

Rivai, Veithzal dan Mulyadi, Deddy. (2012). Kepemimpinan dan Perilaku Organisasi. Edisi Ketiga. Jakarta: PT. Rajagrafindo Persada.

Robbins, Stephen P dan Judge, Timothy A. (2016). Perilaku organisasi (Organizational behavior). Jakarta: Salemba Empat.

Santoso, Sigit, (2015).Pengaruh Kepuasan Kerja, Motivasi Kerja dan Disiplin Kerja terhadap Kinerja Karyawan Bagian Produksi PT. Wijaya Panca Sentosa Food.AGORA Vol. 3, No. 1.

Sardi. (2017). Pengaruh gaya kepemimpinan transformasional dan transaksional terhadap kinerja bawahan melalui kepuasan kerja. Jurnal Bisnis Teori dan Implementasi, Vol. 8 No. 1 : 61-72 Februari 2017, ISSN. 2085-7721 Website: http://journal.umy.ac.id/index.php/bti.

Siswatiningsih, Ida, Raharjo, Kusdi, \& Prasetya, Arik. (2019). Pengaruh kepemimpinan transformasional dan transaksional terhadap budaya organisasi, motivasi kerja, komitmen organisasional dan kinerja karyawan. Jurnal Bisnis dan Manajemen, 5(2).

Sondang, P Siagian. (2004). Teori motivasi dan Aplikasinya. Jakarta: Rineka Cipta.

Sopiah, (2008). Perilaku Organisasional. Yogyakarta: PT Andi Yogya.

Sugiyono, (2000). Metode Penelitian. Bandung: CV Alvabeta.

Suharsim, Arikunto. (2013). Metode penelitian Manajemen. Bandung: Alfabeta.

Sukrajap, Muhamad Ali. (2017). Pengaruh kepemimpinan transformasional terhadap kepuasan kerja dan komitmen organisasional dengan dimediasi oleh pemberdayaan psikologis. Jurnal Psikologi, 12(1).

Suwatno, Hdan Priansa, Donni Juni. (2011). Manajemen SDM dalam organisasi Publik dan Bisnis. Bandung: Alfabeta.

Suyati dan Suhari(2014). Pengaruh kepemimpinan transformasional dan motivasi kerja terhadap kinerja guru yang dimoderasi oleh iklim sekolah di MTs Sekecamatan Winong Kabupaten Pati. Jurnal Nasional ISSN Edisi Khusus No. 2 AgustusTahun 2011.

Wahyu Yulianto. (2018).Pengaruh kepemimpinan transformasional dan kemampuan terhadap komitmen organisasi dengan kepuasan kerja sebagai variabel intervening (studi pada balai pendidikan dan pelatihan aparatur sukamandi). Jurnal Manajemen \& Bisnis Kreatif.vol 4 no 1 (2018)

Wismawati, Endang. (2000). Perilaku Dalam Organisasi. Bandung: Tarsito.

Yukl, Gary. (2010). Kepemimpinan dalam Organisasi, edisi kelima. Jakarta: PT. Indeks.

Zakaria, Z., Noordin, N., Hussin, Z., Sawal, H., \&Zakaria, Z. (2011). The Relationship between Reward Practice and Employees Performance: An EmpiricalStudy.InternationalConferenceonManagement and Artificial Intelligence, 6. 
